\title{
PENGEMBANGAN SPIRITUAL LEADERSHIP DAN \\ PENGARUHNYA TERHADAP LEMBAGA PENDIDIKAN ISLAM \\ Oleh
}

Syarifudin, ${ }^{136}$ dan Deddy Yusuf Yudhyarta ${ }^{137}$

\begin{abstract}
Abstrak
Spiritual Leadership adalah Kepemimpinan yang berorientasi Ketuhanan, Kepemimpinan Spiritual mampu dikatakan kepemimpinan yang sempurna karena mampu menggabungkan nilai Sikap dan etika. Kepemimpinan Spiritual didalam lembaga pendidikan Islam, adalah faktor yang paling penting untuk mewujudkan dan mengembangkan nilai-nilai yang di harapkan dimiliki oleh peserta didik. Memotivasi, serta mendorong penghayatan serta internalisasi nilai-nilai Spiritual menuju kejujuran, tanggung jawab, dan akhlak. Kepemimpinan yang spiritual telah menunjukkan kesuksesannya dalam mengolah Madrasah dan megembangakan SDM di Pendidikan Islam. Hal ini dapat di lihat dari pesatnya perkembangan jumlah siswa dari tahun ke tahun dan sarana serta prasarana yang terus meningkat di Madrasah-Madrasah serta kualitas keilmuannya pun tidak kalah dengan Sekolah umum ataupun Pesantren. Rumusan masalah yang akan di bahas dalam jurnal ini adalah 1) Bagaimana Konsep dasar Kepemimpinan Spiritual? 2) Bagaimana Konsep Spiritual ? 3) Bagaimana Konsep di Lembaga Pendidikan Islam (Madrasah). Simpulan pembahasan dari penelitian jurnal ini, bahwa lembaga pendidikan Islam yang menggunakan kepemimpinan Spiritual-leadership dengan sistem organisasi yang menggerakkan melalui keteladanan, pelayanan, dan implementasi nilai sifat-sifat ketuhanan, dan bisa mengembangkan dan meningkatkan kemampuan lembaga pendidikan Islam melalui rangkaian proses kegiatan yang terjadi di dalam lembaga.
\end{abstract}

Kata Kunci : Kepemimpinan Spiritual, Spiritual-Leadership, Madrasah

\section{Pendahuluan}

\footnotetext{
${ }^{136}$ Dosen Tetap Program Studi Pendidikan Guru Madrasah IbtidaiyahAgama STAI Auliaurrasyidin Tembilahan Kabupaten Indragiri Hilir Propinsi Riau

${ }^{137}$ Dosen Tetap Program Studi Pendidikan Agama Islam STAI Auliaurrasyidin Tembilahan Kabupaten Indragiri Hilir Propinsi Riau.
} 
Madrasah adalah sebuah organisasi yang berbentuk "Human Service Organization" madrasah dapat dikatakan sebagai Lembaga Pendidikan Islam yang sangat menonjol dalam sejarah Islam di Indonesia. Keberadaan madrasah di Indonesia dilatar belakangi oleh kepemimpinan Hindia Belanda. Sampai sekarang madrasah telah menjadi salah satu model pendidikan di seluruh negara Islam, madrasah adalah lembaga pencetak salah satu SDM berkualitas dan bermanfaat bagi Masyarakat tentunya. Keberhasilan Madrasah di tentukan oleh Pemimpinnya mengelolah tenaga Kependidikan yang tersedia di madrasah. Kepala Madrasah sebagai seorang Pemimpin harus mampu mengelolah dan memanfaatkan SDM, yang ada sehingga terjaga efektivitas madrasah pada ujungnya menghasilkan perubahan yang diharapkan pada peserta didik. Kepemimpinan efektif yang selama ini telah dilakukan banyak CEO dan Manager seluruh dunia berkaitan dengan motivasi Pengembangan potensi individu, dan pembentukan tim yang solid.

Beberapa hal yang menjadi masalah lembaga pendidikan Islam yakni mencakup beberapa aspek, seperti mendefinisikan tujuan, menentukan kebijaksanaan, mengembangkan program, mempekerjakan orang, mengadakan fasilitas, mencapai hasil dan mengoordinasikan kegiatankegiatan terpisah-pisah. Semua kegiatan tersebut memerlukan keterlibatan orang- orang dengan latar belakang kemampuan yang berbeda-beda, seperti para guru yang professional, kelompok orang-orang yang tidak terlibat dalam tugas mengajar, seperti pustakawan, laboran dan sebagainya. ${ }^{138}$

Semua orang saat ini membutuhkan Figure kepemimpinan yang dapat di andalkan, di percaya dan mengaktualisasikan perubahan-perubahan konstruktif. Kepemimpinan sebagaimana dikatakan Stogdill yang dikutip

${ }^{138}$ Ahmad Fatah Yasin, Pengembangan Sumber Daya Manusia di Lembaga Pendidikan Islam, (Malang: UIN Maliki Press, 2011) h. 12 
Permadi adalah suatu proses mempengaruhi aktivitas kelompok dalam rangka perumusan dan pencapaian tujuan. Sedang Stephen P. Robbins mengemukakan bahwa "Leadership is ability to influence group a certain to purpose the the goal achievement" kepemimpinan adalah kemampuan mempengaruhi suatu kelompok ke arahpencapaian tujuan. ${ }^{139}$ Kepemimpinan yang mampu mentrasformasikan karakter organisasi, membuat perubahan strategis, sekaligus yang dapat meningkatkan potensi individu-individu yang di pimpinnya.

Kepemimpinan spiritual adalah konsep yang mengadopsi prinsip, kebenaran, ketuhanan, integritas, kredibilitas, kebijaksanaan, belas kasih, yang berorientasi akhlak dan moral diri sendiri dan orang lain untuk mencapai tujuan yang sama. Lembaga pendidikan islam ( madrasah), lebih menekankan kepada tauladan kepemimpinan tersebut, serta etika pemimpin yang mengedepankan moral, mengusahakan sesuatu itu dengan sungguhsungguh, serta dengan baik, benar yang berorientasi kepada Tuhan. Konsep kepemimpinan ini sangat penting, maka pembahasan tentang Spiritual Leadership dan kaitannya di lembaga pendidikan islam akan dibahas lebih dalam dalam jurnal ini.

\section{Hakikat Kepemimpinan Spiritual}

Kepemimpinan berasal dari kata dasar pemimpin. ${ }^{140}$ Dalam Al Qur'an terdapat beberapa lafaz, yang bermakna pemimpi, khalifah, imam dan ulil amri. ${ }^{141}$ Hal senada sebagaimana dikemukakan Nanang Fattah bahwa pemimpin pada hakekatnya adalah seseorang yang mempunyai kemampuan untuk mempengaruhi perilaku orang lain di dalam kerjanya dengan 354

${ }^{139}$ Stephen P. Robbins, Management, (New Jersey: Prentice-Hall, inc., 1991), h. ${ }^{140} \mathrm{CN}$ Cooley " Human Nature and The social Order ( New York, Scribner, 1902), h. 14

${ }^{141}$ M. TH, Thoustma, ( eds), First Enclylopedia Of Islam, Vol IV, ( leiden, : EJ . Brill, 1987), h. 881

110 
menggunakan kekuasaan. Sedang kekuasaan adalah kemampuan untuk mengarahkan dan mempengaruhi bawahan sehubungan dengan tugas-tugas yang dilaksanakan. ${ }^{142}$

Seorang Pemimpin harus memiliki kemampuan mempengaruhi semua anggota atau kelompok agar bersedia melakukan kegiatan untuk mencapai tujuan organisasi. Kepemimpinan adalah kemampuan meyakinkan orang lain agar bekerja sama di bawah pimpinannya sebagai suatu tim untuk mencapai tujuan tertentu). ${ }^{143}$ Dalam pengertian lain, secara etimologi istilah kepemimpinan berasal dari kata dasar "pimpin" yang artinya bimbing atau tuntun. Dari pimpin lahirlah kata kerja "memimpin" yang artinya membimbing dan menuntun. ${ }^{144}$ Sedangkan menurut Hidayat dan Machali, kepemimpinan adalah kemampuan untuk menggerakkan, mempengaruhi, memotivasi, mengajak, mengarahkan, menasehati, membina, membimbing, melatih, menyuruh, memerintah, melarang, dan bahkan menghukum seluruh sumber daya organisasi untuk mencapai tujuan yang diinginkan secara efektif dan efisien ${ }^{145}$.

Kepemimpinan atau leadership merupakan ilmu terapan dari ilmuilmu sosial, sebab prinsip-prinsip dan rumusannya diharapkan dapat mendatangkan manfaat bagi kesejahteraan manusia. Ada banyak pengertian yang dikemukakan oleh para pakar menurut sudut pandang masing-masing, walaupun memang dari definisi-definisi yang diuraikan menunjukkan adanya beberapa kesamaan. Menurut Young, pengertian kepemimpinan yaitu bentuk dominasi yang didasari atas kemampuan pribadi yang sanggup mendorong atau mengajak orang lain untuk berbuat sesuatu yang

\footnotetext{
${ }^{142}$ Nanang Fattah, Landasan Manajemen Pendidikan, (Bandung: Remaja Rosdakarya, 2004) h. 88.

${ }^{143}$ Veithzal Rivai,dkk, Islamic Leadership, ( Jakarta ,Bumi Aksara, 2009), h.106

${ }^{144}$ Ara Hidayat dan Imam Machali, Pengelolaan Pendidikan: Konsep, Prinsip dan Aplikasi dalam Mengelola Sekolah dan Madrasah, (Yogyakarta: Kaukaba, 2012) h.75

${ }^{145}$ Ara Hidayat dan Imam Machali, Pengelolaan Pendidikan..., h. 75
} 
berdasarkan penerimaan oleh kelompoknya, dan memiliki keahlian khusus yang tepat bagi situasi yang khusus. Moejiono, memandang bahwa leadership tersebut sebenarnya sebagai akibat pengaruh satu arah, karena pemimpin mungkin memiliki kualitas-kualitas tertentu yang membedakan dirinya dengan pengikutnya.

Menurut Hermino kepemimpinan merupakan sifat yang dimiliki oleh seseorang yang oleh karena tugas yang diembannnya berusaha untuk memberikan pengaruh kepada pengikutnya (follower) dengan mematuhi terhadap apa yang menjadi instruksi dari orang yang memimpinnya. ${ }^{146}$

Spiritual membawa kita kepada pencarian jati diri lebih mendalam; mencari kebaikan dan potensi terbaik dari dalam diri, menghargai dan memahami orang lain, menumbuhkan kedewasaan berpikir, waspada, bijaksana, membangun rasa belas kasih terhadap orang lain, dan membuat kita bersemangat dalam meningkatkan hubungan rohani dengan Tuhan melalui kegiatan-kegiatan keagamaan yang lebih khusuk dan bermakna. Spiritual mengekspresikan cinta sesungguhnya dari Tuhan, yang tak bersyarat, tidak takut, dan tidak mementingkan diri sendiri. Nilai-nilai kehidupan berorientasi pada kejujuran, perilaku bertanggungjawab, kedamaian bathin, menghindari konflik, dan berakhlak mulia ini berpengaruh dalam pembentukan karakter individu dalam berinteraksi dengan orang lain, bahkan dalam melakukan pekerjaan apapun.

Berdasarkan pendapat para ahli, dapat disimpulkan bahwa Kepemimpinan Spiritual adalah kepemimpinan yang mencakup semua aspek, yang mampu membawa aspek keduniaan dalam aspek kespiritualan, kemampuan mempengaruhi orang lain, mengilhami, membangkitkan,

146 Agustinus Hermino, Kepemimpinan di Era Globalisasi, (Yogyakarta: Pustaka Pelajar, 2014) h. 126

\section{2}


kemampuan mengarahkan melalui keteladanan, yang berorentasi pada Tuhan serta prilaku kepemimpinan.

\section{Hakikat Spiritual}

Istilah "spiritual" berasal dari bahasa inggris yaitu "Spirit" yang memiliki cakupan makna: Jiwa, arwah, roh, atau makna yang hakiki. Spiritual berasal dari bahasa Latin yaitu spiritus yang artinya roh, jiwa atau semangat. Kata ini memiliki padanan dengan Bahasa Ibrani yaitu ruach dan Bahasa Yunani yaitu pneuma yang semuanya diartikan angin atau nafas. Sementara istilah spiritual berasal dari kata dasar Bahasa Inggris yaitu spirit yang memiliki cakupan makna yaitu jiwa, arwah/roh, semangat, hantu, moral, dan tujuan atau makna yang hakiki.

Dalam bahasa Arab, istilah ini juga terkait dengan yang ruhani dan ma'nawi dari segala sesuatu. Dalam Bahasa Indonesia istilah ini dapat diartikan sebagai 'semangat yang menggerakkan'. Dari beberapa istilah di atas, maka spiritual yaitu berbicara tentang hati nurani, moral, serta tingkah laku yang baik dan terpuji dari seseorang maupun dari sekelompok orang dalam masyarakat.

Kata spiritual merupakan suatu kata yang bersifat universal karena bisa digunakan oleh semua agama. Istilah spiritualitas merupakan saripati religius yang ada di balik ajaran atau aturan-aturan formal keagamaan. Pada penghayatan spiritualitas tentu saja ajaran, dogma, atau doktrin suatu agama hanyalah menjadi pijakan semata dalam realitas keagamaan seseorang. Seseorang dapat mengalami perjumpaan dengan Tuhan tentu harus didasari pada nilai-nilai lain sesuai agama yang diyakininya.

\section{Konsep-konsep Kepemimpinan}

Konsep kepemimpinan mempengaruhi memperlibatkan langkah- langkah, kearah keadaan umum dan abstraksi, sehingga secara tidak langsung menyatakan adanya pengaruhyang mengubah tingkah laku. Kepemimpinan 
spiritual merupakan kepemimpinan yang membawa dimensi keduniawian kepada dimensi spiritual (keilahian) dan lebih banyak mengandalkan kecerdasan spiritual dalam kegiatan kepemimpinan (Tobroni, 2005:6).

Kepemimpinan mengalami perkembangan sesuai dengan kondisi yang melatarbelakangi munculnya paradigma kepemimpinan tersebut. Ketika abad ke-19, yakni pada saat revolusi industri kepemimpinan yang muncul adalah paradigma kepemimpinan industri yang menganggap bahwa bentuk kepemimpinan bersifat hierarki dan linear yang dikenal dengan istilah controller leadership. Diakibatkan perkembangan zaman yang dinamis maka konsep kepemimpinan ikut berubah beradaptasi dengan kondisi yang terjadi pada masa itu. ${ }^{147}$

Terdapat tiga konsep Kepemimpinan : Pertama, Konsep yang menganggap bahwa kepemimpinan, merupakan suatu kemampuan yang berupa sifat-sifat yang telah ada sejak lahir, yang ada pada diri seseorang Pemimpin. Menurut konsep ini bahwa kepemimpinan didapat sejak seseorang lahir, konsep ini merupakan konsep yang paling tua. Konsep kedua : memandang Kepemipinan sebagai fungsi kelompok, menurut konsep ini sukses tidak nya sebuah kepemimpinan, tidak hanya di pengaruhi oleh kemampuan, atau sifat- sifatyang dimiliki seseorang, tapi yang yang lebih penting, di pengaruhi oleh sifat-sifat kelompok yang di pimpinnya.

Ketiga merupakan konsep yang lebih maju lagi, konsep ini tidak hanya di landasioleh pandangan, yang bersifat psikologi dan sosiologi, tetapi atas ekonomi dan politisi, konsep ini, menunjukkan betapa pun seorang pemimpin memilii sifat kepemimpnan yang baik, dan dapat menjalankan fungsinya menjadi anggota kelompok, sukses tidaknya kepemimpinan masih di tentukan oleh situasi, yang selalu berubah

\footnotetext{
${ }^{147}$ David Adam Cletzer. "Eco-Leadership in Practice: A Minds Methods Study of County 4-H Programs." Doctoral Disertation, h. 2-7
}

\section{4}


mempengarui, perubahan dan perkembangan kehidupan kelompok yang di pimpinnya. Agar dapat berhasil menjalankan kepemimpinan seharusnya seseorang memiliki, 3 kopetensi dasar 1) Mendiagnosis 2) Mengadaptasi 3) Mengkomunikasikan. Kopetensi diagnosis merupakan kemampuan kognitif yang dapat memahami situasi, saat sekarang yang di harapkan, pada masa yang akan datang, kopetensi mengadaptasi adalah kemampuan seseorang menyesuaikan prilakunya, dengan lingkungannya, sedangkan kopetensi mengkomunikasikan terkait dengan kemampuan seseorang menyampaikan pesan-pesan agar di fahami orang lain dengan bak dan jelas. Pada umumnya komunikasi dilakukan secara lisan, dan verbal yang dapat difahami oleh dua bela pihak. ${ }^{148}$

Masa yang akan datang pemimpin penting memiliki visi yang jelas dan mampu mengkomunikasikan, visi itu agar dapat dengan baik seperti (a) Memimpin dengan Visi yang jelas (b) Memimpin dengan keteladanan (c) seorang komunikator yang terampil (d) Tenang menghadapi situasisituasiyang sulit (e) Mampu mengundang ketidak sefahaman secara konstruktif (f) Tampil dengan citra professional (g) Mampu membuat masalah yang rumit menjadi sederhana ( $h)$ Mampu bekerja dan membangun keberhasilan bersama tim (i) Senang membantu orang lain agar berhasil (j) Seorang pelaku sukses yang sejati (k) Seorang yang menghindari untuk terlibat politik praktis dan tidak menerapkan favoritisme. ${ }^{149}$

${ }^{148}$ Ridwan Raharjo, Leadership Hypnosis Influensing Comanding Empowering Effektively ( CV : Pohon Cahaya, 2012), h. 27

${ }^{149}$ Janse Sinamo, Strategi Adaptik Abad Ke 21 ,( Jakarta : Gramedia, 2000), h. $146-151$ 
Pemimpin mampu menciptakan loyalitas pengikutnya, dalam mencapai aktivitas organisasi, diawali dengan aktivitas individu, efektivitas kelompok dan selanjutnya tercapai efektivitas organisasi. ${ }^{150}$

\section{Konsep Pengembangan Lembaga Pendidikan Islam.}

\section{Hakikat Madrasah}

Kata madrasah dalam bahasa Arab adalah bentuk kata keterangan tempat (zharaf makan) dari kata darasa. Secara harfiah madrasah diartikan sebagai tempat belajar para pelajar atau tempat untuk memberikan pelajaran. ${ }^{151}$ Kata madrasah jika diterjemahkan dalam bahasa Indonesia berarti sekolah, kendati pada mulanya sekolah itu sendiri bukan berasal dari bahasa Indonesia melainkan dari bahasa asing, yaitu school atau scola.

Madrasah dapat dikatakan sebagai lembaga pendidikan yang sangat menonjol dalam sejarah Islam. Madrasah merupakan kelanjutan dari pendidikan mesjid dan pendidikan di lembaga Khan, yaitu mesjid yang dilengkapi dengan asrama. ${ }^{152}$

Penggunaan nama madrasah untuk lembaga pendidikan Islam pada awal-awal Islam mempunyai pengertian yang berbeda dengan pengertian madrasah pada masa sekarang. Pengertian madrasah pada masa klasik Islam disebut sebagai pendidikan akademi (college). Pemberian nama lembaga pendidikan Islam untuk berbagai jenjang dengan nama madrasah ini dapat dipahami mengingat pemberian nama lebih cenderung pada fungsi esensialnya sebagai lembaga pendidikan Islam, yaitu untuk mengembangkan ilmu pengetahuan Islam dan sekaligus menyebarluaskan

\footnotetext{
${ }^{150}$ Abdul Kadim Masaong, dkk, Kepemipinan Berbasis Intelligence, ( Bandung, 2011), h.76

${ }^{151}$ Mehdi Nakosteen, Kontribusi Islam Atas Dunia Intelektual Barat; Deskripsi Analisis Abad Keemasan Islam, (Surabaya: RisalahGusti, 1996), h. 66

${ }^{152}$ A. Malik Fajar, Visi Pembaharuan Pendidikan Islam. (Jakarta: LPNI, 1998), h. 111
} 
paham keagamaan. ${ }^{153}$ Madrasah merupakan bentuk lain dari sekolah yang hanya diberi muatan dan corak ke-Islaman. ${ }^{154}$

Madrasah merupakan lembaga pendidikan Islam khas milik umat Islam, dan lahir dari proses sejarah umat Islam yang panjang, serta dengan lembaga pendidikan madrasah tersebut telah digunakan oleh umat Islam untuk mempelajari berbagai ilmu untuk pengembangan kehidupan umat Islam sepanjang sejarah, terutama di wilayah Nusantara. ${ }^{155}$

Menurut Yahudi Cohen dalam Ahmad menyatakan bahwa suatu lembaga pendidikan pada dasarnya adalah upaya pelembagaan dan formalisasi pendidikan sehingga kegiatan, fungsi, dan proses pendidikan dalam suatu masyarakat bisa berlangsung secara lebih terencana, sistematis, berjenjang, dan professional. ${ }^{156}$ Jika madrasah dianggap sebagai lembaga pendidikan Islam yang sistemik maka unsur dan komponen pokok dalam madrasah seharusnya dikaji secara menyeluruh dan tidak terpisah. Karena unsur dan komponen tersebut akan menjadi bukti bahwa madrasah yang berkualitas unggul seharusnya unsur dan komponennya adalah menyatu, sehingga keberhasilannya adalah menyeluruh. ${ }^{157}$

Jika menggunakan kacamata teori manajemen, dalam mengelola lembaga pendidikan Islam seperti madrasah, maka di dalam kelembagaan pendidikan madrasah tersebut merupakan organisasi yang perlu dikelola dengan pendekatan sistemik. Artinya, madrasah sebagai lembaga pendidikan Islam merupakan sebuah organisasi pendidikan yang di dalamnya terdapat beberapa komponen dalam suatu sistem, dan komponen -

\footnotetext{
${ }^{153}$ Ninik Masrorah dan Umiarso, Modernisasi Pendidikan Islam Ala Azyumardi Azra, (Jakarta: Ar Ruzz Media, 2011), h. 129

${ }^{154}$ Maksum, Madrasah, Sejarah dan Perkembangannya, Cet.2, (Jakarta: Logos Wacana Ilmu, 1999), h. 81

${ }^{155}$ Hasbullah, Sejarah Pendidikan Islam di Indonesia: Lintasan Sejarah Pertumbuhan dan Perkembangan (Jakarta: Raja Grafindo Persada, 1996), h. 66

${ }^{156}$ Ahmad Fatah Yasin, Pengembangan Sumber..., h. 8

${ }^{157}$ Ibid, h. 57
} 
kompoen tersebut memiliki fungsi sendiri - sendiri dan harus berjalan sesuai dengan jobnya masing-masing, serta saling terkait secara integratif. Jika salah satu unsur dalam manajemen madrasah tidak berjalan, maka sistem pendidikan madrasah akan mengalami eror, kurang produktif dan bahkan tidak akan bisa maju. Salah satu komponen penting yang perlu dikelola dengan menggunakan teori manajemen adalah aspek SDM di lembaga madrasah tersebut.

\section{Pengembangan SDM Madrasah}

Menurut Efi Rufaiqah pengembangan sumber daya manusia adalah segala aktivitas yang dilakukan oleh organisasi dalam memfasilitasi pegawai agar memiliki pengetahuan, keahlian, dan/atau sikap yang dibutuhkan dalam menangani pekerjaan saat ini atau yang akan datang. ${ }^{158}$

Madrasah sebagai lembaga pendidikan Islam merupakan sebuah organisasi pendidikan yang di dalamnya terdapat beberapa komponen dalam suatu sistem, dan komponen-kompoen tersebut memiliki fungsi sendirisendiri dan harus berjalan sesuai dengan jobnya masing-masing, serta saling terkait secara integratif. Jika salah satu unsur dalam manajemen madrasah tidak berjalan, maka sistem pendidikan madrasah akan mengalami eror, kurang produktif dan bahkan tidak akan bisa maju. Salah satu komponen penting yang perlu dikelola dengan menggunakan teori manajemen adalah aspek SDM di lembaga madrasah tersebut.

Jika madrasah dianggap sebagai lembaga pendidikan Islam yang sistemik maka unsur dan komponen pokok dalam madrasah seharusnya dikaji secara menyeluruh dan tidak terpisah. Karena unsur dan komponen tersebut akan menjadi bukti bahwa madrasah yang berkualitas unggul

${ }^{158}$ Efi Rufaiqah Muhaimin, “ Tesis : Pengembangan Sumber Daya Manusia Pendidik dan Tenaga Kependidikan di MAN Sumpih Banyumas dan MAN Kroya Cilacap". Manajemen Pendidikan Islam IAIN Purwokerto, 2017, h. 14

\section{8}


seharusnya unsur dan komponennya adalah menyatu, sehingga keberhasilannya adalah menyeluruh. ${ }^{159}$ Berdasarkan pendapat di atas, dapat disimpulkan bahwa apabila kepemimpinan dikaitkan dengan SDM serta Lembaga Pendidikan Islam, (Madrasah), maka pengembangan SDM adalah segala aktivitas yang meliputi proses peningkatan kuantitas maupun kualitas SDM.

\section{Kesimpulan}

Kepemimpinan berasal dari kata dasar pemimpin. Dalam Al Qur'an terdapat beberapa lafaz, yang bermakna pemimpi, khalifah, imam dan ulil amri. Hal senada sebagaimana dikemukakan Nanang Fattah bahwa pemimpin pada hakekatnya adalah seseorang yang mempunyai kemampuan untuk mempengaruhi perilaku orang lain di dalam kerjanya dengan menggunakan kekuasaan. Kepemimpinan Spiritual adalah kepemimpinan yang mencakup semua aspek, yang mampu membawa aspek keduniaan kedalam aspek kespiritualan.

Salah satu komponen penting yang perlu dikelola dengan menggunakan teori manajemen adalah aspek SDM di lembaga madrasah tersebut. Jika madrasah dianggap sebagai lembaga pendidikan Islam yang sistemik maka unsur dan komponen pokok dalam madrasah seharusnya dikaji secara menyeluruh dan tidak terpisah. Karena unsur dan komponen tersebut akan menjadi bukti bahwa madrasah yang berkualitas unggul seharusnya unsur dan komponennya adalah menyatu, sehingga keberhasilannya adalah menyeluruh.

\section{Referensi}


Adam Cletzer, David "Eco-Leadership in Practice ,A Minds Methods Study of County 4-H Programs." Doctoral Disertation. Ala Azyumardi Azra, Ar Ruzz Media: Jakarta. 2011

CN Cooley “ Human Nature and The social Order, Scribner, New York. “1902.

dkk, Veithzal Rivai, Islamic Leadership, Bumi Aksara : Jakarta. 2000

Fajar, A. Malik, Visi Pembaharuan Pendidikan Islam, LPNI, Jakarta. 1998

Fatah Ahmad Yasin, Pengembangan Sumber Daya Manusia di Lembaga Pendidikan Islam, UIN Maliki Press : Malang. 2011.

Fattah, Nanang, Landasan Manajemen Pendidikan, Remaja Rosdakarya : Bandung. 2004

Hasbullah, Sejarah Pendidikan Islam di Indonesia: Lintasan Sejarah Pertumbuhan dan Perkembangan, Raja Grafindo Persada : Jakarta. 1996.

Hermino, Agustinus. Kepemimpinan Pendidikan Di Era Globalisasi. Pustaka Pelajar : Yogyakarta. 2014.

Imam Machali dan Ara Hidayat.. Pengelolaan Pendidikan: Konsep, Prinsip, dan Aplikasi dalam Mengelola Sekolah dan Madrasah, Kaukaba : Yogyakarta. 2012.

M. TH, Thoustma, ( eds), First Enclylopedia Of Islam, Vol IV, leiden, : EJ . Brill, 1987

Maksum, Madrasah, Sejarah dan Perkembangannya, Jakarta: Logos Wacana Ilmu, 1999.

Muhaimin, Efi Rufaiqah, “Tesis : Pengembangan Sumber Daya Manusia Pendidik dan Tenaga Kependidikan di MAN Sumpih Banyumas dan MAN Kroya Cilacap". Manajemen Pendidikan Islam IAIN Purwokerto, 2017

Raharjo, Ridwan, Leadership Hypnosis Influensing Comanding Empowering Effektively, CV: Pohon Cahaya, 2012

Stephen P. Robbins, Management, New Jersey: Prentice-Hall,inc., 1991 